\title{
The orchestra conductor
}

From the authority figure to negotiated order in a vocational profession

\section{Pauline Adenot}

Translator. Maggie Jones

\section{(2) OpenEdition}

\section{Journals}

Electronic version

URL: http://journals.openedition.org/transposition/1296

DOI: 10.4000/transposition.1296

ISSN: $2110-6134$

\section{Publisher}

CRAL - Centre de recherche sur les arts et le langage

\section{Electronic reference}

Pauline Adenot, «The orchestra conductor », Transposition [Online], 5| 2015, Online since 22 November 2015, connection on 30 July 2019. URL : http://journals.openedition.org/ transposition/1296 ; DOI : 10.4000/transposition.1296

This text was automatically generated on 30 July 2019.

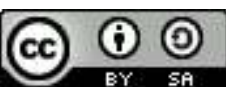

La revue Transposition est mise à disposition selon les termes de la Licence Creative Commons Attribution - Partage dans les Mêmes Conditions 4.0 International. 


\title{
The orchestra conductor
}

From the authority figure to negotiated order in a vocational profession

\author{
Pauline Adenot
}

Translation : Maggie Jones

In both the music world and, more broadly, the social world, the figure of the orchestra conductor is very often represented as having special status: in elevating the conductor as a figure of legitimate or dictatorial power ${ }^{1}$ or archetype of the inspired artist, ${ }^{2}$ the high priest of a now-secular musical mass, sociology, anthropology and the political sciences have long emphasized the emblematic nature of the conductor. In this regard, the concert is a staged representation of the vocational regime, ${ }^{3}$ in which the conductor's artistic personality takes center stage: he is portrayed as an inspired artist, one devoted and committed to music, who leads the orchestra with a masterful hand. The orchestra (consequently perceived as a compact entity in which the individual members disappear) becomes an instrument serving the conductor's own interpretation of the work. This representation intrinsically obscures all of the interactional work that has taken place between the conductor and the instrumentalists, and which is part of the vocational regime.

Yet this perspective-essentially that of the audience-first, shows only one aspect of the actual interactions between the conductor and the orchestra musicians, and second, excludes any notion of external circumstances that may damage his status as the authority, such as difficulties with certain musicians, tensions within the orchestra, the extremely fragile position of a guest conductor, the difficulty of asserting oneself with orchestras that are already well-established institutions, and so on. In fact, the conductor's supposedly "absolute authority" regularly meets resistance (more or less below the surface) and risks being undermined by factors that he has to work around.

In fact, the authority of the conductor seems actually to be a social construct which is created behind the scenes during the rehearsals. More precisely, the authority we could define as contractual-that which comes automatically with the conductor's positionensures the orchestra's relative obedience and would therefore, one would think, be sufficient for a work relationship. However, as orchestral and musical endeavors require more than mere obedience, most conductors seek the musicians' true adherence to their 
interpretation, which can only be obtained once the conductor's professional legitimacy has been established in the eyes of the musicians, endowing him with what we shall refer to as professional authority. ${ }^{4}$

Drawing on an ethnographic study of three permanent orchestras, this article attempts to show the process by which this authority is co-constructed by the conductor and the orchestra during the rehearsals-the authority, it seems, which alone allows the conductor to obtain the instrumentalists' true adherence to his interpretation-not just in principle but backed by their conviction as musicians. To this end, we will first present our ethnographic study, the various methods used, and a summary of our observations and findings. We will then distinguish between contractual authority and professional authority, and attempt to shed light on the process by which professional authority is constructed through the interactions between the conductor and the orchestra.

\section{An ethnographic study within the orchestra}

\section{Contextual framework and method of the study}

This article is based on a multilocal fieldwork study conducted from 2001 to 2007 on three different ensembles: the Orchestre de l'Opéra de Paris, the Orchestre National de France and the Orchestre de l'Opéra de Lyon. These orchestras were chosen on the basis of their geographic location, which allowed for compared analysis, and their formal characteristics. First, these orchestras represent two types of ensembles: on-stage orchestras (which are visible to the audience) and pit orchestras (which play below the stage for opera or ballet performances, and are therefore partly hidden from view and on the outskirts of the audience's attention). The distinction between the two is apparent particularly in the way the concert is staged: the ritual of introducing the conductor and the orchestra is simpler and more succinct for a pit orchestra, since the musicians are less exposed. Only the conductor is positioned high enough to be visible to the audience, in order to be able to coordinate the orchestra with the performance on stage and the soloists' parts.

These orchestras also fall under the category of permanent orchestras. ${ }^{5}$ Most of the world's leading orchestras-positions in which are particularly sought-after by musicians -are permanent orchestras. Many are institutions, having a history of some duration which may or may not serve as a reference for the musicians. In France, musicians in permanent orchestras generally refer to their orchestra as "la maison" or "la grande maison " (which loosely translates as "the company"), emphasizing its historic significance and prestige. ${ }^{6}$ The Orchestre de l'Opéra de Paris, in its oldest form, was created in the seventeenth century. Today it counts 174 musicians distributed between two orchestras, so that it is able to cover simultaneous performances at the Palais Garnier and Opéra Bastille. The Orchestre National de France, created in 1934, is the oldest permanent orchestra in France and today counts 112 musicians. Lastly, the Orchestre de l'Opéra de Lyon, was created in 1983 and is composed of 61 musicians. While geographic mobility is a significant part of an orchestra musician's career, ${ }^{7}$ permanent orchestras tend to represent a fixed working structure for musicians, for whom, consequently, working with a permanent orchestra is often a very strong part of their professional identity. This is not without consequence for the conductor and something he needs to consider, 
especially when assuming the command of a full-fledged ensemble that has existed for quite some time, with its own potentially well-established identity and habits.

Within these orchestras, the conductor's position may be two-pronged: he may be not only the principal conductor but also the orchestra's music director. According to the terms of his contract, he is obligated to give a set number of performances per year with the orchestra, while remaining free to direct other ensembles outside of this primary engagement. ${ }^{8}$ As an orchestra's season is not limited to the concerts it gives with the principal conductor, the administration rounds out its musical program by inviting guest conductors (of varying experience and prestige) to head the orchestra in his absence. These guest conductors may be engaged for a single concert or a series of performances, and the number of rehearsals at their disposal is adjusted accordingly. For example, the principal conductor and music director of the Orchestre de l'Opéra de Paris, Philippe Jordan, will conduct thirty-five of the 334 performances during the 2014-2015 season, i.e., approximately ten percent. The rest of the performances will be directed by twenty-five guest conductors. Establishing authority with the orchestra can be particularly difficult for guest conductors: with their varying degrees of experience, and regardless of how long their assignment will last, they need to quickly win the approval of the orchestra, which may be tired of working with "maestros" who come and go and whose talent for conducting is, from the musicians' perspective, variable.

Our study included the ethnographic observation of many rehearsals and concerts, sometimes over a long period, e.g., more than a year without interruption at the Opéra de Paris. Thanks to this extended presence in the orchestra milieu, we were also able to conduct dozens of formal and informal interviews with orchestra musicians and with some ten orchestra conductors.

\section{Ethnographic observation of rehearsals}

Our ethnographic observation of rehearsals shows that, as in other professional milieus, the reality of the interactions differs from the representations of the conductor as a figure of absolute authority. The study provided insight into the dynamics that actually play out during rehearsals and helped clarify the musicians' role in establishing someone in the role of conductor. The relatively long duration of the study and our multilocal approach allowed us to observe a large number of rehearsals, some with principal conductors and others with guest conductors. While, given the unique personality of each conductor and orchestra, there is no such thing as a "standard" rehearsal, we were able to distinguish several invariants in the way rehearsals are set up. ${ }^{9}$

First, whether the principal conductor or a guest, a new conductor's arrival at the head of a orchestra is never neutral: the two sides face each other, each observing the other and trying to determine the personality and expectations of the party across from them. Both instrumentalists and conductors say that this initial contact is almost always a power struggle, at least symbolically, regardless of whether or not the conductor is renowned, or whether or not he has a certain prestige and recognition in the music world. As one musician said, "There are those who need to be dominated. If you don't dominate them, they will dominate you. [...] If they are not subdued by the conductor, they'll try to destabilize him-to knock him down. So the conductor has only one option: when he arrives he needs to be the strongest. A power struggle." This "power struggle" can take different forms and does not necessarily involve confrontation: a musician might pretend not to understand a foreign conductor 
with a heavy accent, a section might be chatting during rehearsal just to see how long the conductor will go without saying something, or a musician might ask an ingenuous question about the work just to test the conductor's knowledge, and so on. The first rehearsal is often a sort of faceoff in which both sides test each other's expertise and personality.

When the actual rehearsing begins, and if the work is new to the orchestra or to this orchestra-conductor pairing, the usual practice is to begin with a reading, meaning to play either the entire work or entire movements once through. This is the musicians' chance to see the general direction the conductor will take in his interpretation. Most of the time, but not always, the conductor introduces the work to the musicians, providing insight into its historical context and musicological considerations that he feels are important. Far from trivial, these "educational" moments are in fact a significant part of the conductor's role (almost in the theatrical sense) and of his function in the eyes of many musicians: "Conductors are often the kind of people who know a million things. They must have read...they read fifteen books a week. They are always poring over scores. They are incredibly cultivated."

Next, the conductor decides to work on specific passages, not necessarily in the order in which they appear in the work, but rather according to particular difficulties they present, either technically or interpretation-wise. This is where the differences in conductors' working methods first become apparent: some conductors like to work section by section ${ }^{10}$ while others prefer working with the entire orchestra; some organize partial rehearsals-that is, sessions with only the strings or only the horns or woodwinds, etc. -in order to work with precision and in greater depth; some like to organize attendance such that musicians who are not playing can arrive later or leave earlier, while others prefer that all members of the orchestra be present to listen to their colleagues' work and to be fully immersed in the interpretation. This decision often affects the mood among the musicians, most of whom are not very fond of staying in their seats without playing for two-thirds of the rehearsal.

The conductor may also decide to work on specific orchestral excerpts ${ }^{11}$ involving a single instrumentalist, and this is when a certain tension can be felt in the orchestra: tension for the musician playing alone in front of his peers, tension for the rest of the orchestra who have no idea how many times their colleague will have to play the same thing, and tension for the conductor who knows he is engaging in a perilous interaction for himself and the musician. If he is too insistent, making the musician play it again and again, the musician could "lose face"12 which might in turn lead to some degree of conflict; but if he relents too easily, he risks not getting the interpretation he wants. The difference in how conductors handle this type of situation is often a question of experience: novices tend to be more insistent, not taking into consideration what is also at stake for the musician. To the observer, the musician's irritation is perceptible, as is the unease among his colleagues, who manifest their support in various ways, such as shifting restlessly on their chairs, grumbling about the conductor's insistence in less-than-hushed voices, calling for the rehearsal to resume, and talking amongst themselves.

Throughout this type of work, the conductor gives instructions, not all of them in formal language: he may use the vocational vernacular (a mix of technical and musical terms), but as music is experienced corporally, he may also resort to singing, miming and onomatopoeia, either because he thinks they will help get his meaning across, or, more basically, because his command of French is limited, or for both of these reasons. Most 
foreign conductors who are not fluent in French will speak English, but the level of comprehension the musicians display is often revelatory about their relationship with the maestro (in other words, this can be a highly effective technique for destabilizing the conductor, who is left with only gestures to make himself understood).

The way rehearsals are formally organized and conducted reveals something quite different than a relationship of dedication to the conductor: every conductor has a particular rapport with each orchestra, which sometimes even varies from one section to another. No rules regarding this interaction can be drawn from ordinary representations of the music world. The orchestra-conductor relationship, and particularly the authority that will be granted to the conductor, is something which is constructed through interaction within a negotiated order. All of the conductors and most of the instrumentalists that we met acknowledged that the relationship between the conductor and the orchestra is based first and foremost on a power relationship, mainly because the conductor is alone at the head of an ensemble (of up to a hundred people and more) and needs to find a way not only to make himself heard, but to be obeyed: "There is definitely a power relationship between an orchestra and a conductor. It can be more or less strong, or more or less gentle, but there is a dominator/dominated relationship, although it can shift from one moment to another: sometimes it's the conductor and sometimes it's the orchestra-one dominating the other."

The conductor can be more or less firm and authoritarian, or on the opposite end of the spectrum, more or less flexible and conciliatory; this depends not only on his personality but also a wide range of factors including the orchestra's mood or the rehearsal framework. For example, one conductor we interviewed spoke about the difficulty of dealing with confrontation with the orchestra, especially when working as a guest conductor: "If they [the musicians] only respond with a head-on power struggle, it's best to just back down. Otherwise the relationship becomes hostile, and when that happens, the orchestra always wins. Because they are there, on their own turf." Another conductor talked about the need to adapt to the orchestra:

For example, say we're going over a passage in a work during rehearsal. On one hand, you have in mind the version that, let's say, you want to achieve, the interpretation criteria that you give the orchestra, what you want to hear; on the other hand, there is what you are actually hearing. So you have to respond to that and sometimes find a middle ground between your interpretation and what the orchestra is providing. Because first, the orchestra, and the sound it has and its musical ideas [...], sometimes it just won't work and you have to find a middle road.

For its part, the orchestra can be more or less resistant, cooperative, attentive or argumentative; different sections in the orchestra may respond differently to the same conductor, some with straightforward cooperation, others with distance or hostility. This resistance is not systematic and cannot be consistently attributed to a given orchestra or conductor; it can appear from the first rehearsal or develop gradually. It can come in the form of an anonymous remark, sighs and shrugging of shoulders, side conversations, or more direct verbal confrontation ("we don't understand what you're doing at all"). The musicians can be more or less distracted, deciding to place a book in front of their score, sending text messages during measures they don't play, or chatting with their neighbor (or even with the observer, who is inadvertently drawn into the dynamic). This resistance can border on outright refusal to follow the conductor's instructions: "For example, you ask for something and they simply don't do it"; "I even have musicians who shake their heads 'no' at me." However-and we will see further on the significance of this distinction-in most 
cases, the orchestra behaves this way when it is unconvinced about what the conductor is asking, that is, when the conductor (as he is well aware) has failed to convince them, to win their support.

These different attitudes and interactions show that the orchestra is not an inanimate instrument that the conductor can play as he wishes. The conductor definitely needs the musicians' cooperation, and they have more or less subtle ways of letting him know this. In short, if every orchestra-conductor relationship is not the same, it is because the nature of the relationship they will have is a co-construction which both parties in each pairing help to create.

\section{Co-construction of the conductor's authority}

\section{The different types of authority}

As we have said, the conductor is very often associated with a figure of absolute power. Yet observation of the work that goes on in rehearsals shows that not only is this authority far from absolute, but also that it can take many different forms. Not all conductors have equal authority over orchestras, and the same conductor may be granted a different type of authority by different sections in an orchestra. This has a very important consequence, which is that the conductor's different forms of authority give rise to different forms of legitimacy with the orchestra, and thus different degrees of adherence to his interpretative designs.

In the humanities and social sciences, authority is generally considered to be both a legitimate form of power (because the majority believes that it is justified ${ }^{13}$ ), and a relational concept in which each player has the ability to negotiate (even if the resources on which this ability is based are not equivalent for both parties). It is this second sense, the essential interactional relationship, that we will focus on here to help us understand the construction of the conductor's role. While legitimacy does foster adherence to authority, the nature and degree of this adherence can vary depending both on the individuals involved in the exercise of authority and the ways in which it is exercised.

Nevertheless, there is the question of the nature of legitimacy. In the sociological tradition, theorist Max Weber was the first to propose a hierarchical classification of different justifications for authority. He distinguished three types of legitimate rule: traditional authority, charismatic authority, and rational (or legal-rational) authority. ${ }^{14}$ The last two types are of particular interest here as they reflect the authority exercised by most orchestra conductors. Moreover, from the perspective of each individual instrumentalist, the same conductor may demonstrate both these types of authority.

Ethnographic observation shows that legal-rational authority seems to be a given in any meeting between a conductor and an orchestra, but also that this form of authority endures in the relationship between the two parties, ${ }^{15}$ regardless of the quality of that relationship. In other words, it is a contractual type of authority based on the orchestra's formal statutes. The terms of the statutes can differ from one orchestra to another, but they all place the conductor at the head of the orchestra. ${ }^{16}$ This legal-rational, or contractual, authority automatically ensures the conductor basic legitimacy, if only because he is the musicians' "boss" (to apply a rather problematic term to this sometimes complex artistic and legal framework). This is enough to guarantee him a minimum level of service ${ }^{17}$ from the instrumentalists-e.g., attending rehearsals and concerts, technically 
executing what is written in the score (from the notes and rhythm to the notated nuances), following the conductor's most obvious gestures (the tempi and more pronounced nuances), etc.-such that no musician would ever dream of not following the conductor (which does not mean a musician will not take certain liberties if there is a clash between them). Thus, the conductor can rely on certain givens, such as the instrumentalists' personal experience, which translates into a host of indeterminate skills and perspectives. This informal knowledge also constitutes a form of professional socialization, as much for young instrumentalists as for young conductors, serving as a form of memory of one's profession background, development and transformations, which also plays a role in the necessary interaction between the conductor and the orchestra. Most conductors say they realize that the orchestra could get along without them ("You need to be humble enough to admit to yourself that eighty percent of the time, the orchestra could play alone"), at least for certain works, or with only minimal arrangements. Yet conductors and orchestras both understand that to be at their best and to fulfill their respective commitments, the latter definitely needs the former.

It is interesting to note that contractual authority by no means prevents acts of resistance or opposition on the part of the musicians: in this regard, as with any professional organization, the orchestral ensemble is a social construct resulting from the potentially divergent goals and interests of the various participants. As sociologists Michel Crozier and Erhard Friedberg ${ }^{18}$ have shown, no organization holds such absolute authority over its employees that it can keep the various actors from behaving according to their own rationality. Instrumentalists have areas of uncertainty ${ }^{19}$ at their disposal, which they may or may not choose to exploit: for example, when a musician is absent, it is generally up to the other members of his section to choose a substitute; for a musician, being able to choose one's colleague, even temporarily, is a significant area of autonomy. Depending on whether the substitute is a novice or an experienced orchestra musician, the result is very different for the conductor, who does not-or not easily-have much say in the matter. Along the same lines, musicians can decide how strictly or loosely to apply the rules. Thus, they may essentially play with the rules, which can result in quite a spectacle for the observer: some rehearsals end precisely at the set time, mid-movement, leaving the conductor literally with his arms in the air. The rules say the musicians can leave at the designated hour, and to stay later is a concession to the conductor, and one that he must earn. Similarly, while the rules say the musicians must be present on time for the start of a rehearsal, they do not specify that the instrument must be ready to be played. As certain instruments take time to prepare, it is up to the musicians' discretion to arrive ahead of time in order to warm up their instrument, or not.

Nevertheless, rehearsals are the time and place in which conductors try to transcend the contractual relationship in order to establish their professional legitimacy. They all know that they need the majority of the orchestra to not only participate, but truly embrace the project if they are to realize their interpretation of the work. In other words, while contractual authority ensures some degree of obedience from the musicians, only the orchestra's true recognition of the conductor provides the professional authority he needs for a successful artistic endeavor. 


\section{The bases for professional legitimacy}

As we have said, it would seem that the professional legitimacy per se of any conductor presenting himself to an orchestra for the first time is never automatic, either to him or the musicians. Whether novices or experienced conductors, they all have to go through the "testing phase". ${ }^{20}$ Legitimacy here is obtained through a process and can never be assumed or taken for granted. As one conductor said, "It's not even clear that I'm the one setting the tempo; that means there is a problem." Professional legitimacy is constructed through interaction, and can be invalidated at any time: even the most renowned and highly reputed conductors cannot assume that an orchestra will be behind them at the first rehearsal. ${ }^{21}$ The work of the conductor involves fine-tuning each instrumentalist's playing technique-the unique and eminently personal technique they have patiently crafted over many years. The musician's technique is his area of autonomy-in the sound, the nuances, the articulations and attacks, etc. All of these elements are essential to the conductor, and he is dependent upon the instrumentalist to provide them. Yet these very elements are part of the musician's musical and professional identity: his particular sound or type of attack function as a sort of business card, representing his professional "added value", and he will not necessarily be receptive to them being called into question by the conductor. Thus, when the conductor wants to adjust a musician's instrumental playing technique, it is a delicate negotiation in which the conductor is not always in a position of power.

Through our cross-analysis of the interviews conducted with conductors and musicians, it appears that professional legitimacy is based on three components: mastery of the work being played, well-founded musical interpretation, and skill in managing the group.

\section{Mastery of the work being played}

The first component of professional legitimacy is based on the most perfect possible mastery of the work that is going to be played, including both musical mastery (knowing each section's part, making the decisions for balance, etc.) and technical mastery ( handling changes of meter, anticipating changes in tempo, etc.). For the conductor, it is a matter of knowing the score by heart, and especially knowing it better than the musicians do ("You need to know the score better than they do, that's for sure"), not only to be able to answer any question they may ask, but also to justify his choices by referring to the text itself-the only base of reference shared by both conductor and orchestra. Remaining faithful to the score leaves little leeway for the conductor's personal interpretation; only thorough knowledge of the text will allow him to explain and, if necessary, justify each of his decisions. As one of the conductors interviewed explained: "To be reassured, I need to be better than the orchestra. [...] I need to have that musical advantage. If I feel barely up to par... it is very uncomfortable for me. And I think they can sense it." Indeed, the lack of perfect masterywhether real or imagined-is one of the main factors that contribute to a conductor being destabilized by the musicians, as this allows them to: "[...] challenge the conductor's legitimacy. And this opens the door to other problems. If he is not legitimate, [the musicians] can challenge his tempo, his nuance, his interpretation, and then there is no stopping them."

Another key skill (again, both technical and musical) which depends on the conductor's mastery of the score is the precision of his gestures. Most conductors have theorized the 
question of gesture, and think it is closer to the ineffable part of music that words cannot express:

I operate on the premise that during rehearsal, we are there to play as much as possible. To speak as little and play as much as possible. [...] Because the regard and gesture conveys much more than words. I am not a poet. I'm not Rimbaud, so I can express things with my regard, with gestures and with the body that are subtler and closer to music, which itself is really very subtle: it is difficult to describe music.

Moreover, musical gesture conveys more than the music; it also conveys the conductor's attitude towards the orchestra. During our observation, the researcher noticed that the conductor uses gestures-crossing or uncrossing the hands or arms, turning his ear, "calling on" a musician in the back with his baton-to show that he is listening to a specific musician or section in particular, or to show a certain musician his approval or disapproval. A dialog is unfolding between the conductor and the orchestra, and as in any meaningful exchange, this requires both parties' participation.

It seems that precision of gesture is, in itself, a form of authority, reflecting both the conductor's intention and his connection to the orchestra, such that lack of precision can cause a deficit in legitimacy and thus authority, ${ }^{22}$ especially if the conductor has to rely too heavily on speaking. Indeed, musicians seem always circumspect with a conductor who is over-verbal in explaining what he wants to do: when, in their view, a conductor talks too much, they suspect he is in some way incompetent. It is interesting to note that instruction at the Conservatoire National Supérieur de Musique (CSNM) ${ }^{23}$ focuses particularly on gesture: one of the conductors interviewed reported that during his first three years of study at the CSNM, the instruction he was given was not to talk to the musicians during his conducting exercises, to ensure that he was effectively communicating through gesture. In short, most orchestras balk at the over-use of speech, as conductors are well aware. One conductor summed up the instrumentalists' attitude this way: "If you're not able to show it, well, then we're not interested." The use of gesture is where the conductor's technical skill comes into play-his ability to play his own instrument.

\section{Well-founded musical interpretation}

The second factor in professional legitimacy is what we have labeled "well-founded musical interpretation", or in other words, the ability to justify one's interpretative choices-which nevertheless remain highly subject to contradiction-by pointing out elements in the score that the musicians had not noticed:

A musician can never criticize a conductor for making music [...]. This is what gives you legitimacy as a conductor-because legitimacy in the eyes of the musicians is the most difficult to obtain-and your legitimacy is based on the music you have in your head, and nothing else. [...] The reason you are there in front [of the orchestra], and that it is relevant for you to be there, is the music you have in your head, which is unique to you, and which you are going to transmit to the musicians.

On further analysis, however, this notion of well-founded musical interpretation was found to encompass two distinct realities. On one hand, the conductor must be able to justify his interpretative choices (determining whether or not he obtains the musicians' approval in principle), including during his co-construction of the interpretation with the orchestra, ${ }^{24}$ which for some conductors is a source of ideas and suggestions that is necessary to their interpretation. As one conductor said: 
What I do is give a direction to things: the relationship between different elements-to me, that is what the conductor does. Constructing, of course, assisting with the theme; that's basic. But in more complex music, knowing that this part is more important than that one [...], you need someone to guide you. To me, that is really the conductor's role. And then [indicating] the emotional direction of things, but in a broad sense-in a general manner. So that the whole orchestra is going in one direction. Then inside [the work], the phrasings, the little phrasings, and if they don't do it, it doesn't work!

But again, the goal is to obtain the orchestra's adherence, as this conductor expresses:

But then, it's true, you have to be careful [...], because you need to be sure of the result and sure that, somehow, people will like it. Or that even if they don't like it, that it works and is a musical or logical choice, or in any case, that it is coherent [...]. What I mean is that even if people don't like it, it needs to be convincing, in fact. For the musicians, so that they can do it well.

On the other hand, well-founded musical interpretation also seems to involve what can only be characterized as a form of charisma: certain conductors win the musicians' adherence by the sheer force of their conviction, without necessarily needing to justify their choices. This type of conductor, observed in rehearsal, will ostentatiously ignore comments by musicians who seem to have doubts about his interpretation, until he gets exactly what he wants to hear. After the concert, the musicians in question will tell us that the conductor was right after all, without being able to justify this either. Thus, conductors like this can acquire a certain status-that of a leader potentially capable of transcending the orchestra with the music he has "in his head", as the conductor cited above put it. An orchestra musician interviewed by the American sociologist Robert Faulkner talked about the charismatic quality of a true conductor, specific to the vocational regime:

I think W. has that personality, he has that quality. He knows exactly what he wants us to do and he conveys it, the concert last night was exciting, really. He has that charisma. It's just their personality, that's the mark of a good conductor. He can make you want to play as good as you can for him, he gives you that confidence. I think you can tell when a man gets up there whether or not he has it, they just have a certain personal magnetism, it's hard to explain. ${ }^{25}$

Here, the conductor's charisma stems as much from his conducting abilities or interpretive inspiration as his ability to convince the orchestra of the validity of his interpretation. Once acquired, this sentiment of legitimacy can transform the orchestraconductor relationship; the conductor will feel he has the legitimacy to exercise a certain form of authority, and that even if there are tensions with the orchestra at times, he knows he will prevail:

The justifications also need to be valid. That's how I manage to justify them: it's because I really believe in them strongly [...]. Sometimes there are things I don't really like, but...well, it doesn't matter so much. But other things, no, they are important. Tempo, it's one of the most important things in music. To me. I don't let that slide. Until I've got the right tempo, I keep redoing it.

This quote illustrates even when legitimacy has been acquired, some elements are negotiated with the orchestra so that others, those that are particularly important to the conductor, don't need to be. Even when based on professional legitimacy, the authority is never absolute.

However, it must be said that a conductor's charismatic power does not necessarily win over the entire orchestra: he may be charismatic for some, but not for others. Whether or not a conductor possesses charisma seems to depend overwhelmingly and paradoxically 
on external factors, rather than his own qualities: the general mood of the orchestra, the work being played, possible fatigue within the orchestra, the social, cultural and sometimes political climate, ${ }^{26}$ and so on, which explains why nothing can ever assumed or be taken for granted. ${ }^{27}$

\section{Managing the group}

The myth around the figure of the conductor has generated representations and metaphors which have little to do with the reality of the profession, but have nevertheless become a part of the collective imagination. The metaphor of the conductor found its way into the surge of management theories emerging over the past halfcentury, ${ }^{28}$ while at the same time the idea of the conductor as manager seems to have permeated the orchestra world. Many conductors use the term "management", more or less ironically, to qualify the essential task of managing the group, which is not part of their training. It involves overseeing and coordinating a wide-range of parameters, staying attuned to the general atmosphere in the orchestra and the musicians' energy level or fatigue, determining whether it is a good time to start difficult work or to put it off until the next rehearsal ("You persist with something whereas, well... you need to sense that, no, it's time to move on. Don't overdo it"), picking up on boredom, stopping the orchestra or not, and paying attention to musicians who don't have anything to play, ${ }^{29}$ etc. Managing the rehearsal is often defined as "the key to a project's success": "If you don't know how to manage a group, the orchestra will quickly turn their back on you, and we won't be able to make music together in any case, because both sides have not [...] found common ground."

Managing the orchestral group seems primarily to be an art of compromise, allowing certain attitudes so that others can be avoided, and these aspects seem to reflect the conductor's connection to the orchestra. As one conductor said, "Again, when it's chaotic [in rehearsal], chaos doesn't really bother me. It's not only them. I tolerate it as well." The art of compromise means being able to evaluate which wry comments by the musicians need to be taken into account, or which issue needs to be resolved immediately and which can wait until the next rehearsal; it means communicating an idea to a head of section in a way that prompts him to suggest a correction to his colleagues on his own, so that the conductor does not have to call them out publicly.

When the orchestra is accompanying a concert soloist, this adds a whole other dimension to the conductor's management role: the conductor finds himself in a balancing act, sharing decisions he would normally take as music director with the soloist (to varying degrees, depending on the soloist's renown) while at the same time being one with the orchestra. This situation, i.e., playing with a concert soloist, is the only musical situation in which conductors use "we" rather than "I/they" to describe their connection to the orchestra.

Semantic analysis of these interviews reveals a specific vocabulary of interaction and exchange: the conductor needs to learn to adapt to the orchestra, to not only work with it as it is, but to be receptive to suggestions. "It's actually more of an exchange [...]. For me, my idea is more to share and be inspired," said one conductor. Ultimately, managing the group also seems to involve a form of seduction ("You are in front of a group, you want to win them over; that's also part of it"). In reality, it is a perpetual negotiation, and it is up to each party to determine what, to it, is most important. 
Thus, to recap, the professional legitimacy of the conductor appears to be based on these three invariants-mastery of the skills, well-founded musical intention, and the ability to manage the group. And this legitimacy is constructed during the rehearsals, through the interactions between the orchestra and the conductor. However, no conductor ever achieves unanimous approval: contractual authority only becomes professional authority when the majority of musicians in the orchestra grant the conductor their recognition.

The orchestra conductor is often presented as a metaphor for autocratic power. The vocational regime that governs artistic universes has perpetuated this representation in the collective unconscious: because he is considered to be a chosen one endowed with a gift, the conductor is seen as holding the truth about the musical work, and therefore justified in imposing the force of his intention on an entire orchestra. Yet, while many musicians, in the broadest sense, continue to speak of their work in music as a vocationa calling-it is no less a profession which is part of a complex organizational system governed by interactions between actors with their own objectives and agendas. In this regard, observation of rehearsals shows that to a large extent, the fact that the conductor's role is defined in the statutes does not necessarily guarantee his authority with the instrumentalists. Here, even the notion of legitimacy must be nuanced, for while all conductors have contractual authority, not all conductors obtain the professional recognition of the musicians (or at least most of them) that they need to engage them in a true artistic endeavor. As in many other professions, the conductor's authority is built through interaction and, to some extent, through partnership with the musicians. The case of the guest conductor is particularly exemplary of this, as the difficulties and hurdles that a principal conductor may face are concentrated within a short period. Thus, in addition to the predominance of the regime of singularity in social representations of artistic universes, our ethnographic study reveals the importance of there also being a professional regime that will govern and regulate the interactions between the different artists, whether conductors, instrumentalists or concert soloists.

Finally, we wish to specify that all of the conductors encountered and a number of the instrumentalists said they see overt contradiction and contesting as a particularity of French orchestras. This cultural trend, which it would be interesting to analyze in subsequent research, seems to stem from the soloistic method in which French instrumentalists are trained. Based on a teaching ideology which is still excessively oriented towards a career as a concert soloist-in the tradition of uniqueness and singularity tracing back to the Romantic era-and which largely disregards the profession of orchestra musician (in that it is perceived as a failed career), music schools continue to not really train musicians for orchestra playing. Thus, the instrumentalists who join these ensembles have received a very high level of instruction, making them highly skilled musicians who are trained to reflect deeply on the music and its interpretation, but who are ill-prepared for orchestral work and utterly ill-at-ease with the idea of following someone else's musical interpretation, which they perceive as submitting to the conductor. Consequently, this submission is never automatic and can always be retracted on any misstep by the conductor: as extreme experts in their instrument who are fully aware of their musical worth, musicians will only agree to submit to another if he has been able to demonstrate his even greater worth. 


\section{BIBLIOGRAPHY}

ADORNO, Theodor W., Introduction à la sociologie de la musique. Douze conférences théoriques, transl. V. Barras et C. Russi, Genève, Éd. Contrechamps, 1994.

BECKER, Howard S., Art Worlds, ed. updated and expanded, Berkeley (Calif.), University of California Press, 2008.

BECKWITH, Annabelle, «Improving Business Performance - The Potential of Arts in Training ", Industrial and Commercial Training, Vol. 35, No. 5, 2003, p.207-209.

BOUDON, Raymond and BOURRICAUD, François, A Critical Dictionary of Sociology, transl.

P. Hamilton, Chicago, Routledge, 1989.

BOURDIEU, Pierre, The Rules of Art. Genesis and Structure of the Literary Field, transl. S. Emanuel, Stanford (Calif.), Stanford University Press, 1996.

BRAUD, Philippe, Sociologie politique, Paris, Éditions LGDJ, 2011.

BUCH, Esteban, «Le chef d'orchestre. Pratiques de l'autorité et métaphores politiques », Annales. Histoire, Sciences sociales, $57^{\mathrm{e}}$ année, No. 4, 2002, p.1001-1028.

BUTEAUX, Arièle, « Un peuple en habit noir », Autrement, No. 99, 1988, p.70-77.

CASANOVA, Vincent, « Baguettes tradition », Vacarme, Vol. 3, No. 48, 2009, p.24-25.

COENEN-HUTHER, Jacques, « Pouvoir, autorité, légitimité », Revue européenne des sciences sociales, T. XLIII, No. 131, 2005, p.135-145.

CROZIER, Michel and FRIEDBERG, Erhard, L'Acteur et le système. Les contraintes de l'action collective, Paris, Éd. du Seuil, 1977.

FOUCAULT, Michel, Dits et écrits, T. 2, Paris, Gallimard, 2001.

FOUCAULT, Michel, Discipline and Punish. The Birth of the Prison, transl. A. Sheridan, New York, Vintage Books, 1995.

FURTWÄNGLER, Wilhelm, Musique et verbe, transl. J.-G. Prod'homme, F. Goldbeck et al., Paris, Le Livre de Poche, 1979.

GOFFMAN, Erving, Interaction Ritual. Essays on Face-to-Face Behavior, Garolen City (NY), Anchor/ Doubleday, 1967.

HEINICH, Nathalie, L'Élite artiste. Excellence et singularité en régime démocratique, Paris, Gallimard, 2005.

HUNT, James G., STELLUTO, George and HOOIJBERG, Robert, « Toward New-Wave Organization Creativity: Beyond Romance and Analogy in the Relationship Between Orchestra-Conductor Leadership and Musician Creativity ", The Leadership Quarterly, Vol. 15, No. 1, 2004, p.145-162.

LEHMANN, Bernard, L'Orchestre dans tous ses éclats. Ethnographie des formations symphoniques, Paris, La Découverte, 2005.

LEHMANN, Bernard, «L'envers de l'harmonie », Actes de la recherche en sciences sociales, Vol. 110, 1995, p.3-21.

LIÉBERT, Georges, Ni empereur ni roi, chef d'orchestre, Paris, Gallimard, 1995. 
LIÉBERT, Georges, L'Art du chef d'orchestre, Paris, Fayard, 2013.

MERLIN, Christian, Au cœur de l'orchestre, Paris, Fayard, 2012.

MINTZBERG, Henry, « Covert Leadership: Notes on Managing Professionals », Harvard Business Review, 1998, p.140-147.

SCHLANGER, Judith, La Vocation, Paris, Hermann, 2010.

SORIGNET, Pierre-Emmanuel, Danser. Enquête dans les coulisses d'une vocation, Paris, La Découverte, 2012.

WEBER, Max, Economy and Society. An Outline of Interpretative Sociology, ed. G. Roth and C. Wittich, Berkeley (Calif.), University of California Press, 1978.

WEBER, Max, Essays in Sociology, ed. and transl. H.H. Gerth and C. Wright Mills, Oxon, Routledge, 2009.

WILLENER, Alfred, La Pyramide symphonique. Exécuter, créer? Une sociologie des instrumentistes d'orchestre, Zürich, Seismo, 1997.

\section{NOTES}

1. See, for example, BUCH, Esteban, “Le chef d'orchestre : pratiques de l'autorité et métaphores politiques", Annales. Histoire, Sciences sociales, $57^{\text {th }}$ year, No. 4, 2002, p.1001-1028.

2. For an ethnographic presentation of the staging of the concert and the figure of the conductor, see LEHMANN, Bernard, "L'envers de l'harmonie", Actes de la recherche en sciences sociales, Vol. 110, 1995, p.3-21. For reflections on the conductor's role and characteristics, see ADORNO, Theodor W., Introduction à la sociologie de la musique. Douze conférences théoriques, transl. V. Barras et C. Russi, Geneva, Éditions Contrechamps, 1994 or MERLIN, Christian, Au cœur de l'orchestre, Paris, Fayard, 2012.

3. Or "regime of singularity" ("régime de singularité") as defined by Nathalie Heinich. See, for example, HEINICH, Nathalie, L'Élite artiste. Excellence et singularité en régime démocratique, Paris, Gallimard, 2005. For an example of the structural predominance of vocation, see SORIGNET, Pierre-Emmanuel, Danser. Enquête dans les coulisses d'une vocation, Paris, La Découverte, 2012, about ballet dancers.

4. Wilhelm Furtwängler, for the centennial of the Vienna Philharmonic Orchestra, has already pointed out the co-existence of these two regimes of authority and the precedence of one over the other: "At first, this may seem to be very characteristic: the 'Philharmoniker' (as they are called) elect their own conductor, which is very unusual, especially in the century of the authoritarian state. But even in the state of Germany, the Weiner Philharmoniker were granted their autonomy. In art, the principle of authority works in a peculiar way: what I would call external authority is, of course, an important factor, but if it is not connected to the inner authority from which all true artistic ability stems, then is spite of all our efforts, we will wait in vain for the legitimately expected results." See FURTWÄNGLER, Wilhelm, Musique et verbe, transl. J.-G. Prod'homme, F. Goldbeck et al., Paris, Le Livre de Poche, 1979, p.310. Ultimately, only legitimacy granted directly by the instrumentalists themselves would allow a true artistic process to be engaged in.

5. France's twenty-six permanent orchestras, based in the regions' major cities or within opera houses, are subsidized by the government, either through state funding or by local and regional authorities.

6. This is less true in the case of the Orchestre de l'Opéra de Lyon, which is more recent. 
7. In the study conducted by Xavier Dupuis in 1996, seventy percent of permanently employed instrumentalists had previously worked with other orchestras and one fourth said they would like to change orchestras in the coming years. Let us keep in mind that there is much less turnover in the most renowned orchestras, which require a high level of instrumental skill and are much harder to get positions in. See DUPUIS, Xavier, Les Musiciens professionnels d'orchestre. Étude d'une profession artistique, Paris, Ministère de la Culture et de la Francophonie Département des Études et de la Prospective, 1996.

8. In practice, especially in the case of renowned conductors, they generally take over as the orchestra's music director, with gives them full authority in matters such as choosing the repertory.

9. The observations we set out herein represent a summary of various rehearsals observed with different conductors, who always had a particular rapport with each orchestra.

10. This term refers to an ensemble of musicians belonging to the same family of instruments.

11. An orchestral excerpt consists of several measures to be played by a single instrumentalist or section. It may a technical exercise in virtuosity, but it may also be an extremely musical excerpt, wherein the difficulty is of a different nature.

12. In the sense of the term "face" defined by Erving Goffman as "the positive social value a person effectively claims for himself by the line others assume he has taken during a particular contact" (GOFFMAN, Erving, Interaction Ritual. Essays on Face-to-Face Behavior, Garolen City (NY), Anchor/Doubleday, 1967).

13. "We talk about the authority of a person, of an institution or of a message, in order to signify that we have confidence in them, that we welcome their advice, suggestions or commands with respect, that we look upon them favourably or at least without hostility or resistance, and that we are ready to defer to them." (BOUDON, Raymond and BOURRICAUD, François, A Critical Dictionary of Sociology, transl. P. Hamilton, Chicago, Routledge, 1989).

14. Max Weber defined charistmatic authority as "resting on devotion to the exceptional sanctity, heroism, or exemplary character of an individual person, and of the normative patterns or order revealed or ordained by him." He defined rational authority as "belief in the validity of legal statute and functional 'competence' based on rationally created rules" in which case "obedience is expected in discharging statutory obligations. See WEBER, Max, Essays in Sociology, ed. and transl. H.H. Gerth and C. Wright Mills, Oxon, Routledge, 2009, p.78-79.

15. If the relationship is too conflictual, this may lead to the conductor's resignation-as in the case of Charles Dutoit with the Montreal Symphony Orchestra in 2002-but rarely results in mutiny, i.e. the orchestra as a whole refusing to comply with the conductor's contractual authority.

16. Contractually, the musicians of the Opéra de Paris and the Orchestre National de France are under the authority of the music director (in the case of the former, they are under the joint authority of the music director and the director of the Opéra de Paris). When the conductor is not the music director-as is the case for a guest conductor-the musicians are under the authority of the concertmaster (a legal resurgence of the "Konzertmeister"). In Lyon, the musicians are under the adminsitrative authority of the mayor and the musical authority of the principal conductor, but these statutory nuances are purely symbolic in practice.

17. According to Max Weber, with legal-rational authority, the obeying party has a "sense of duty" such that failing to fulfill a contractual obligation "would be abhorrent to his sense of duty (of course, in varying degrees)". See WEBER, Max, Economy and Society. An Outline of Interpretative Sociology, ed. G. Roth and C. Wittich, Berkeley (Calif.), University of California Press, 1978, p.31.

18. CROZIER, Michel and FRIEDBERG, Erhard, L'Acteur et le système Les contraintes de l'action collective, Paris, Éd. du Seuil, 1977.

19. Areas of uncertainty can be defined as areas in which an actor has a certain freedom of action and which are beyond the organization's control. 
20. LOGIE, Nicholas uses the expression "testing phase" in The Role of Leadership in Conducting Orchestras, doctoral dissertation in philosophy, Edinburgh, The Open University, 2012. - "And this [assessing the orchestra] is partly why this first moment in which the two forces judge each other is so full of suspense: each studies the other and tries to guess what kettle of fish he will shortly be dealing with. And a great number of things are decided at that first contact. Sometimes, it determines whether a concert will be good or not" (Riccardo Muti cited in MATHEOPOULOS Helena, Maestro. Encounters with Conductors of Today, London, Hutchinson, 1982, p.363).

21. A condcutor's notoriety may even be a handicap: at one first rehearsal we observed, presided by a world-famous conductor, many members of the orchestra were on guard precisely because of the conductor's international renown, as if they were poised to unmask a figure they saw as a potential usurper.

22. "Not surprisingly, inadequately defined cues and cognitions not only lack authoritativeness, they are themselves generators or causes of subsequent conduct such as open disrespect, sullenness, deliberately lowered work effort, selective inattention, sarcasm, and in general the making and taking of role distance" (FAULKNER, Robert R., "Orchestra Interaction: Some Features of Communication and Authority in an Artistic Organization", The Sociological Quarterly, Vol. 14, No. 2, 1973, p.151).

23. As the only higher education institution in France to offer a masters in orchestra conducting, the Conservatoire de Paris (CNSM) is where the vast majority of French conductors are trained.

24. Keeping in mind, however, that orchestra sections are not all equal when it comes to making suggestions: it is much more frequent among woodwind and horn players, who are fewer in number and all more or less playing their parts as soloists, which means it is easier for them to speak on their own behalf. We can go as far as to hypothesize here that the various sections in an orchestra form their relationship with the condcutor differentially, partly for this very reason.

25. FAULKNER, "Orchestra Interaction: Some Features of Communication and Authority in an Artistic Organization", art. cit., p.152.

26. See BUCH, Esteban, "L'Orchestre de Paris et Daniel Barenboïm dans l'Argentine du général Videla : la musique et le silence de la mort", Relations internationales, No. 156, 2014, p.87-108.

27. A 2005 study conducted on twenty-two orchestras in Germany showed that the reality and effectiveness of the charismatic conducting method are highly dependant on the orchestra's mood and motivation, demonstrating that charismatic conducting actually stems from the interaction between the conductor and the musician. See BOERNER, Sabine and FREIHERR VON STREIT, Christian, "Transformational Leadership and Group Climate: Empirical Results from Symphony Orchestras", Journal of Leadership \& Organizational Studies, Vol. 12, No. 2, 2005, p.31-41.

28. Peter Drucker is the first author to use this analogy, in 1950. See DRUCKER, Peter, The New Society. The Anatomy of the Industrial Order, New York, Harper \& Brothers, 1950.

29. Which is in the conductor's best interest. As one conductor said, "You need to know that when a musician isn't playing, he is listening."

\section{ABSTRACTS}

In musical and social representations, the orchestra conductor is portrayed as a figure of autocratic power, one whose authority is recognized and accepted by all. In reality, however, this 
authority is a social construct which is created over the course of the rehearsals. Moreover, it is highly dependent on the type of legitimacy held by the conductor, i.e., contractual legitimacy, which remains minimal, or professional legitimacy, which is based on the instrumentalists' approval and recognition. This article attempts to understand which criteria allow this professional legitimacy to be established, for only this can allow the musicians to truly embrace the conductor's interpretation.

The first part of this article presents our ethnographic study of three symphonic orchestras. The second part distinguishes between contractual legitimacy and professional legitimacy and then explores the process by which the latter is constructed in orchestra-conductor interactions.

INDEX

Keywords: Orchestra conductor, Instrumentalists, Legitimacy, Authority, Profession, Vocation

\section{AUTHORS}

\section{PAULINE ADENOT}

Pauline Adenot holds a PhD in sociology and musicology and is a research engineer at Telecom ParisTech Institute. After completing her dissertation on symphonic orchestra musicians, she is now focusing her research on score composers and the effects of using new technologies in the writing process. 